\title{
OXIDATIVE/ANTIOXIDANT BALANCE AND MATRIX METALLOPROTEINASES LEVEL IN THE KNEE CARTILAGE OF RATS UNDER EXPERIMENTAL OSTEOARTHRITIS AND PROBIOTIC ADMINISTRATION
}

\author{
O. KOROTKYI , K. DVORSHCHENKO, L. KOT, \\ T. VOVK, M. TYMOSHENKO, L. OSTAPCHENKO \\ ESC “Institute of Biology and Medicine”, \\ Taras Shevchenko National University of Kyiv, Ukraine; \\ 凶e-mail: korotkyi@gmail.com
}

Received: 28 June 2020; Accepted: 13 November 2020

\begin{abstract}
The aim of this work was to investigate the effect of the poly-strain probiotic on oxidative-antioxidant balance and the level of matrix metalloproteinases (MMPS) in rat knee cartilage under experimental osteoarthritis. Osteoarthritis was induced by a single injection of monoiodoacetate into the knee joint of rats. Probiotic was administered daily for 14 days. Knee cartilages homogenate was used to evaluate the content of reactive oxygen species (superoxide anion and hydrogen peroxide), products of lipids peroxidation (diene conjugates, TBA-active compound, Shiff bases), to determine superoxide dismutase and catalase activity and activity of glutathione-dependent antioxidant enzymes, the level of reduced and oxidized glutathione. The level of MMPS -1, -2, -3, -8 expression was estimated by ELISA. Osteoarthritis was found to cause a significant increase in the reactive oxygen species level, lipid peroxidation products content, superoxide dismutase and catalase activity, level of all studied MMPs, and also depletion of glutathione-dependent antioxidant system and the decrease in the ratio between reduced and oxidized glutathione.The administration of the probiotic was followed by the tendency for the restoration of the parameters to the values of the control group. Thus, the administration of the probiotic to rats with osteoarthritis may be considered as an anti-inflammatory and antioxidant agent for further clinical trials.
\end{abstract}

Ke ywords: osteoarthritis, probiotic, free radical processes, glutathione, matrix metalloproteinases.

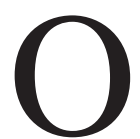
steoarthritis (OA) occupies an important place among the diseases of the joints. OA develops in $90 \%$ of the population over 65 years old, in some of them it leads to the development of disability. Moreover, the risk of OA increases by mechanical injuries, infectious diseases and metabolic disorders [1-3]. From the modern point of view, OA is the heterogeneous group of diseases of various etiologies, with similar biological, morphological, and clinical consequences. The pathological process involves not only articular cartilage but all joint structures - subchondral bone, ligaments, joint capsule, synovial membrane, and periarticular muscles, so OA is now considered as a disease of the whole joint [4]. Recent studies showed data on the potential association between the development of OA and the state of the microbiome in the digestive tract $[5,6]$. The state of the microbiome is also closely related to the pathogenesis of some metabolic and inflammatory diseases, that may involve in the development of OA. Factors such as stress, use of medication such as nonsteroidal anti-inflammatory drugs may lead to the formation of oxidative stress in intestines and have been found to contribute to intestinal dysbiosis [7]. Therefore, the study of the mechanisms that link the participation of intestinal microflora in the development of joint diseases becomes urgent. Our previous results and the works of the colleagues showed promised results of multistrain probiotic (PB) “Symbiter ${ }^{\circledR}$ ” to maintain

(C) 2020 Korotkyi O. et al. This is an open-access article distributed under the terms of the Creative Commons Attribution License, which permits unrestricted use, distribution, and reproduction in any medium, provided the original author and source are credited. 
and restore normobiosis of the gastrointestinal tract (GIT) in various experimental models [8-10]. Understanding the links between the state of intestinal microflora and the development of the inflammatory processes may help to predict destructive processes in the joint on the early stage of OA. The progression of inflammation in the joints is intensified by free radical processes, that lead to damage of synovial cells, destruction of cartilage, erosion of bones, and joint surfaces [11, 12]. Matrix metalloproteinases (MMPs) affect the metabolism of extracellular matrix components and concerned as markers of joint tissue destruction [13, 14]. In our previous studies, we found the effect of multistrain PB on the system disruption of free radical processes and levels of MMPs in the bloodstream during experimental OA $[15,16]$, however, the local biochemical mechanisms of these processes were not shown in the cartilage yet. Therefore, the aim of this study to investigate the effect of a multistrain live probiotic on the oxidative-antioxidant balance and activity of MMPs in the cartilage of rats under conditions of experimental osteoarthritis.

\section{Materials and Methods}

Bioethical statement. The study included participation of white male non-linear rats (8 weeks old, weighing 180-240 g). The animals were hold at 12 light $/ 12$ dark cycles, $18-23^{\circ} \mathrm{C}$ temperature and 40 $60 \%$ humidity. All animals got free access to water and standard nutrition. The rats were divided on four experimental groups ( $n=14$ for each group, 56 total), each animal was weighed once a week to correct therapeutic doses. In this study we followed the general ethical principles of experiments on animals adopted by the First National Congress of Ukraine on Bioethics (September 2001) and other international agreements in this field.

Induction of experimental model of osteoarthritis. Injection of $0.05 \mathrm{ml}$ of saline containing $1 \mathrm{mg}$ sodium monoiodacetate (MIA) (Sigma, USA) in the patellar ligament of hind knee (or saline only as control) [17].

Administration of probiotic composition. In this study we used water solution of manufacturer PB composition Multiprobiotic Simbiter ${ }^{\circledR}$ (O.D. "Prolisok", Ukraine). According to manufacturer description, it is a complex included live symbiotic biomass that contains 17 strains of microorganisms belonging to 10 species: Bifidobacterium bifidum, B. longum, Lactobacillus acidophilus, $L$. delbrueckii, L. helveti- cus, Propionibacterium freudenreichii, P. acidipropionici, Lactococcus lactis, Acetobacter aceti, Streptococcus salivarius [18]. Animals got daily dose of $\mathrm{PB}, 140 \mathrm{mg}$ of PB diluted in $1 \mathrm{ml}$ of water per $1 \mathrm{~kg}$ of animal weight.

Study design. As it described above, animals divided in four groups. I - Control: injection of saline in knee joints at $1^{\text {st }}$ day and daily administration of water from the $8^{\text {th }}$ to the $21^{\text {st }}$ of the experiment. II - PB: injection of saline in knee joints at 1st day and daily administration of $\mathrm{PB}$ composition from the $8^{\text {th }}$ to the $21^{\text {st }}$ of the experiment. III - MIA-OA: injection of MIA in knee joints at $1^{\text {st }}$ day and daily administration of water from the $8^{\text {th }}$ to the $21^{\text {st }}$ of the experiment. IV - MIA-OA+PB: injection of MIA in knee joints at $1^{\text {st }}$ day and daily administration of PB composition from the $8^{\text {th }}$ to the $21^{\text {st }}$ of the experiment. The experiment terminated at $30^{\text {th }}$ day according to bioethical statement, the knee joints were removed for further preparation of samples.

Cartilage homogenization. Knee joints stored in plastic tubes at $-80^{\circ} \mathrm{C}$ for no more than 3 months before homogenization. Homogenization performed in 3 phases: 1) mechanical grinding at room temperature; 2) mechanical chopping in a porcelain mortar with liquid nitrogen; 3) automated homogenization with 1X PBS (Sigma, USA) in 1:10 ratio to a weight of cartilage via Ultra Sonic T10 Basic (IKA, Germany) at $3000 \mathrm{rpm}$ for $3 \mathrm{~min}$. Unhomogenized parts were removed by centrifugation on 1-15K Centrifuge (Sigma, USA) at $3000 \mathrm{rpm}$ for $15 \mathrm{~min}$. Supernatants was stored in plastic tubes for further tests no more than 1 week at $-20^{\circ} \mathrm{C}$.

Quantative optical spectroscopy. The level of the superoxide radical was tested by the formation of HTT-formazan [19]. The level of hydrogen peroxide was measured in sorbitol-xylenol orange [20, 21]. The level of diene conjugates and Shiff bases was tested in heptane-isopropyl phases of samples [22, 23]. The reaction with thiobarbituric acid (TBA) were used to measure level of TBA-active compounds [24]. Superoxide dismutase activity was tested by the ability of the enzyme to compete with nitrosin tetrazolium for superoxide radicals [25]. The catalase activity was measured by the amount of undiluted hydrogen peroxide in the sample [26]. Glutathione peroxidase (GP) activity was evaluated by decreasing reduced glutathione (GSH) content in reaction with the Elman reagent [27]. Glutathione transferase (GT) activity was determined by the rate of formation of the GSH conjugate with 1-chloro-2,4-dinitroben- 
zene [27]. Glutathione reductase (GR) activity was measured by decreasing the optical density of the samples during the oxidation of NADPH [27]. The level of GSH and oxydized glutathione (GSSG) was determined by spectrofluorimetric method using ophthaldehyde at different $\mathrm{pH}$ values $[28,29]$. Total proteins in sampes were measured by reaction with Folin phenol reagent [30].

Enzyme-linked immunosorbent assay (ELISA). Commercial ELISA kits (Biotrak ELISA System, Healthcare, USA) were used for valuation of MMP-1, MMP-2, MMP-3, MMP-8 in cartilage homogenates, with strict following of manufacturer instructions.

Statistical analysis. The results were presented as average arithmetic \pm standard deviation (dispersion) - SD. Normal distribution was checked via the Shapiro-Wilk test for normality and conducted to one-way ANOVA with Tukey's post hoc test for multiple comparisons. Two-sided $P \leq 0.05$ was considered statistically significant. The results were analyzed using GraphPad Prism 5.04 (GraphPad Software Inc., USA).

\section{Results and Discussion}

The development of OA enhances free radical processes in chondrocytes that disrupt the structural and functional state of cartilage cells and leads to the death of chondrocytes and synoviocytes [31]. Excess of hydrogen peroxide, superoxide radical, and nitric oxide are synthesized in cells due to the action of proinflammatory cytokines. The signaling cascades activate collagenase and inhibit protease inhibitors. It leads to the peroxidation of lipid membranes and damage of enzymes [32].

In this study, we investigated the parameters linked to the development of oxidative stress in cartilage tissue started by MIA-induced OA (Table 1).
We found an increase in the level of superoxide radical in 3.1 times and hydrogen peroxide in 1.7 times in homogenate of cartilage, compared to the Control group. The administration of PB to animals with MIA-OA decreased the level of superoxide radical in 1.9 times and hydrogen peroxide in 1.5 times in homogenate of cartilage, compared to the MIA-OA group. The same conditions of $\mathrm{PB}$ administration to animals without MIA-OA did not cause significant changes in study parameters, compared to the Control group.

Thus, our results showed an increase in the levels of reactive oxygen species under conditions of MIA-OA in cartilage tissue that indicates the activation of free radical processes directly in the joint. The administration of PB caused the decrease of ROS in cartilage tissue of rats under conditions of experimental OA that indicates possible antioxidant properties od studied PB composition.

Mechanical overload of the joints promotes the generation of mitochondrial superoxide anion radical and selective inhibition of superoxide dismutase 2 in chondrocytes in vivo, while experiment in vitro showed that mitochondrial superoxide anion radical inhibits expression of superoxide dismutase in chondrocytes. The deficiency of the enzyme in chondrocytes leads to excessive production of the mitochondrial superoxide anion radical, which causes cartilage degeneration [33].

Hydrogen peroxide in normal physiological concentration is an important signaling molecule. However, increasing hydrogen peroxide in chondrocytes can trigger NF- $\kappa B / M A P K$ cascade that activates the expression of proinflammatory cytokines and autoimmune degradation of cartilage tissue [34]. ROS may interact with components of cells and cause oxidation of lipids. The levels of the

Ta b le 1. The levels of reactive oxygen species in cartilage tissue of knee joints of rats with monoiodoacetateinduced osteoarthritis (MIA-OA) and administration of probiotic (PB) composition ( $n=14$ in each group)

\begin{tabular}{l|c|c}
\hline \multirow{2}{*}{ Group } & \multicolumn{2}{|c}{ Parameter } \\
\cline { 2 - 3 } & $\begin{array}{c}\text { Superoxide anion radical, } \\
\mu \text { mol XTT formazan } \times \text { mg protein }^{-1}\end{array}$ & $\begin{array}{c}\text { Hydrogen peroxide, } \\
\mu \text { mol } \times \text { mg protein }^{-1}\end{array}$ \\
\hline Control & $8.03 \pm 0.76$ & $12.83 \pm 1.15$ \\
PB & $7.63 \pm 0.52$ & $11.32 \pm 1.03$ \\
MIA-OA & $24.95 \pm 2.17^{*}$ & $22.39 \pm 2.08^{*}$ \\
MIA-OA+PB & $13.21 \pm 1.15^{* / \#}$ & $14.73 \pm 1.17^{\#}$ \\
\hline
\end{tabular}

${ }^{*} P<0.05$ compared with Control group; ${ }^{\#} P<0.05$ compared with MIA-OA group 
interactions valuated by the content of lipid peroxidation (LPO) products - diene conjugates (primary products), TBA-active compounds, the main component of which is malonic dialdehyde (secondary products) and Schiff bases (final products) $[35,36]$. Similar processes also occur in the tissues of the joints, particularly in cartilage.

Our study showed, experimental OA induced by monoiodoacetate increase the level of LPO products in cartilage homogenates (Table 2). The level of diene conjugates increased in 2 times, the level of TBA-active products increased in 2.3 times, the level of Schiff bases increased in 2.1 times, compared to Control group. Administration of PB to animals with MIA-OA decreased the level of LPO in cartilage homogenates: diene conjugates and Schiff bases in 1.9 times and TBA-active products in 1.7 times, compared to MIA-OA group.

Obtained data confirmed intensification of LPO under the conditions of experimental OA, induced by MIA injection in the knee, as it showed by the increase of diene conjugates, TBA-active products and Schiff bases in cartilage homogenates. The detected decrease in LPO products in the cartilage of rats under conditions of experimental OA and administration of PB composition may indicate the antioxidant effect of this composition. The administration of PB to animals without experimental OA did not disturb the levels of studied LPO compounds in cartilage homogenates, compared to control group.

Similar results obtained by other studies. Shan showed in vitro an increase of the content of LPO products, malonic dialdehyde and hydroxynonenal in chondrocytes [37]. Articular cartilage does not have blood vessels, and the supply of oxygen in cartilage tissue is limited. Cell metabolism is well adapted to hypoxia; however, chondrocytes are sensitive to oxy- gen. The studies in vitro showed that hypoxia promotes the expression of the chondrogenic phenotype and the formation of a specific cartilage matrix. It indicates the importance of maintaining a certain level of oxygen partial pressure in cell culture. Moreover, the effects of oxygen itself, reactive oxygen species play an important role in the regulation of a number of major metabolic types, such as chondrocyte cell activation, matrix proliferation, and remodeling. However, when ROS generation exceeds the antioxidant potential of the cell, the development of oxidative stress lead to structural and functional cartilage damage such as cell death and matrix degradation [38-40]. Abusarah showed in vitro oxidation of cartilage matrix proteins by malonic dialdehyde, that caused changes in the biochemical and biophysical properties of cartilage tissue [40]. The development of oxidative stress shows in the synovial fluid of patients with osteoarthritis, accompanied by increased production of activated oxygen metabolites $\left(\mathrm{H}_{2} \mathrm{O}_{2}\right.$, NO*) and activation of LPO (malonic dialdehyde). It is linked with inhibition of antioxidant system (superoxide dismutase, catalase, GP, decreased content of GSH).

Intensification of free radical oxidation and strengthening of prooxidant properties in synovial fluid of patients with osteoarthritis depends on the severity of the pathological process or the severity of surgery during arthroscopy, and it contributes to the deepening of destructive-dystrophic changes of articular cartilage and increased apoptosis [41, 42]. The anti-radical enzymes superoxide dismutase and catalase are the first lines of protection of cells from free radicals. Superoxide dismutase catalyzes the dismutation of superoxide to oxygen and hydrogen peroxide. It plays a crucial role in the antioxidant protection of almost all cells that contact with oxy-

Table 2. The levels of lipid peroxidation products in cartilage tissue of knee joints of rats with monoiodoacetate-induced osteoarthritis (MIA-OA) and administration of probiotic (PB) composition $(n=14 \mathrm{in}$ each group)

\begin{tabular}{l|c|c|c}
\hline \multirow{2}{*}{ Group } & \multicolumn{3}{|c}{ Parameter } \\
\cline { 2 - 4 } & $\begin{array}{c}\text { Diene conjugates, } \\
\text { nmol } \times \text { mg protein }\end{array}$ & $\begin{array}{c}\text { TBA-active compounds, } \\
\text { nmol } \times \text { mg protein }^{-1}\end{array}$ & $\begin{array}{c}\text { Shiff bases, rel. units } \\
\times \text { mg protein }^{-1}\end{array}$ \\
\hline Control & $279.88 \pm 18.27$ & $65.21 \pm 6.18$ & $8.06 \pm 0.72$ \\
PB & $271.67 \pm 15.35$ & $61.07 \pm 5.73$ & $7.84 \pm 0.68$ \\
MIA-OA & $570.14 \pm 22.81^{*}$ & $149.97 \pm 12.36^{*}$ & $16.91 \pm 0.68^{*}$ \\
MIA-OA+PB & $294.41 \pm 21.39^{*}$ & $87.42 \pm 8.05^{* / \#}$ & $8.85 \pm 0.76^{\#}$ \\
\hline
\end{tabular}

${ }^{*} P<0.05$ compared with Control group; ${ }^{*} P<0.05$ compared with MIA-OA group 
gen in one of many possible ways. Catalase performs a protective function against hydrogen peroxide. The decomposition of hydrogen peroxide into molecular oxygen and water activates by catalase and it is carried out in two stages. Also, oxidized catalase may work as as a peroxidase and catalyze the oxidation of alcohols or aldehydes. About 5\% of the oxygen, formed as a product of catalase reducing of hydrogen peroxide goes into the excited singlet state. Thus, catalase can be a source of ROS [43].

In our study, experimental OA increased superoxide dismutase activity in 4 times, and catalase activity in 4.8 in cartilage tissue, compared to control group (Table 3). Administration of PB to animals with MIA-OA reduced superoxide dismutase activity in 2.4 times, and catalase activity in 3.6 times, compared to MIA-OA group. Administration of PB to animals without conditions of experimental OA keeped the enzyme activity within values of control group.

The second protective antioxidant link is the glutathione-dependent antioxidant system (GDAS) that not only neutralizes ROS but also is able to restore oxidation products. So, our next step was to investigate the activity of the GDAS in rat cartilage under conditions of experimental OA and administration of PB.

We found that the development of experimental OA reduced the activity of enzymes of the GDAS in cartilage tissue: GP in 1.8 times, GT in 1.7 times, GR in 2 times, compared to control group (Table 4). The conditions of OA disturbed the ratio between GSH and GSSG (Table 5). Thus, the levels of GSH decreased in 1.9 times and GSSG increased in 1.7 times, compared to relative values of control group. The administration of PB to animals with experimental OA increased activities of enzymes of GDAS: GP and GT in 1.5 times, GR in 1.7 times, compared to MIA-OA group. PB helped to restore the ratio of GSSG and GSH in the cartilage of rats with experimental OA. Thus, the level of GSH increased in 1.7 times, the level of GSSG decreased in 1.5 times, compared to MIA-OA group. Also, administration of PB to healthy animals caused in-

Table 3. Antiradical enzymes activity in cartilage tissue of knee joints of rats with monoiodoacetate-induced osteoarthritis (MIA-OA) and administration of probiotic (PB) composition ( $n=14$ in each group)

\begin{tabular}{l|c|c}
\hline \multirow{2}{*}{ Group } & \multicolumn{2}{|c}{ Parameter } \\
\cline { 2 - 3 } & $\begin{array}{c}\text { Superoxidedismutase activity, } \\
\text { unit } \times \mathrm{min}^{-1} \times \mathrm{mg} \mathrm{protein}^{-1}\end{array}$ & $\begin{array}{c}\text { Catalase activity, } \\
\mathrm{nmol} \times \mathrm{min}^{-1} \times \mathrm{mg}_{\text {protein }}{ }^{-1}\end{array}$ \\
\hline Control & $0.321 \pm 0.029$ & $14.21 \pm 1.25$ \\
PB & $0.314 \pm 0.031$ & $13.68 \pm 1.19$ \\
MIA-OA & $1.281 \pm 0.105^{*}$ & $67.49 \pm 6.38^{*}$ \\
MIA-OA+PB & $0.527 \pm 0.048^{*, \#}$ & $18.91 \pm 1.77^{* / \#}$ \\
\hline
\end{tabular}

${ }^{*} P<0.05$ compared with Control group; ${ }^{~} P<0.05$ compared with MIA-OA group

Ta ble 4. Enzymes activity of glutathione-dependent antioxidant system in cartilage tissue of knee joints of rats with monoiodoacetate-induced osteoarthritis (MIA-OA) and administration of probiotic (PB) composition ( $n=14$ in each group)

\begin{tabular}{l|c|c|c}
\hline \multirow{2}{*}{ Group } & \multicolumn{3}{|c}{ Parameter } \\
\cline { 2 - 4 } & $\begin{array}{c}\text { Glutathione peroxidase } \\
\text { activity, nmol GSH } \times \\
\text { min }^{-1} \times \mathrm{mg} \mathrm{protein}^{-1}\end{array}$ & $\begin{array}{c}\text { Glutathione transferase } \\
\text { activity, nmol } \times \text { min- } \\
1 \times \text { mg protein }^{-1}\end{array}$ & $\begin{array}{c}\text { Glutathione reductase } \\
\text { activity, nmol NADPH } \times \\
\text { min }^{-1} \times \text { mg protein }^{-1}\end{array}$ \\
\hline Control & $11.64 \pm 1.15$ & $3.12 \pm 0.28$ & $0.14 \pm 0.01$ \\
PB & $10.95 \pm 1.04$ & $2.81 \pm 0.25$ & $0.14 \pm 0.01$ \\
MIA-OA & $6.41 \pm 0.62^{*}$ & $1.84 \pm 0.17^{*}$ & $0.07 \pm 0.01^{*}$ \\
MIA-OA+PB & $9.75 \pm 0.83^{\#}$ & $2.71 \pm 0.61^{* / \#}$ & $0.12 \pm 0.01^{\#}$ \\
\hline
\end{tabular}

${ }^{*} P<0.05$ compared with Control group; ${ }^{*} P<0.05$ compared with MIA-OA group 
Ta b le 5. The levels of reduced (GSH) and oxidized (GSSG) glutathione in cartilage tissue of knee joints of rats with monoiodoacetate-induced osteoarthritis (MIA-OA) and administration of probiotic (PB) composition ( $n=14$ in each group)

\begin{tabular}{l|c|c}
\hline \multirow{2}{*}{ Group } & \multicolumn{2}{|c}{ Parameter } \\
\cline { 2 - 3 } & GSH, nmol $\times \mathrm{mg}_{\text {protein }}^{-1}$ & GSSG, mol $\times$ mg protein $^{-1}$ \\
\hline Control & $7.21 \pm 0.69$ & $2.48 \pm 0.23$ \\
PB & $8.73 \pm 0.81^{*}$ & $2.35 \pm 0.21$ \\
MIA-OA & $3.84 \pm 0.37^{*}$ & $4.17 \pm 0.39^{*}$ \\
MIA-OA+PB & $6.42 \pm 0.51^{*}$ & $2.82 \pm 0.23^{* / \#}$ \\
\hline
\end{tabular}

${ }^{*} P<0.05$ compared with Control group; ${ }^{\sharp} P<0.05$ compared with MIA-OA group

crease of GSH in 1.2 times, compared to control, group, other studied parameters of GDAS remained within control values.

The decrease of GP, GT, GR activity, and the level of GSH indicates depletion of GDAS in experimental OA. This is due to the growth in the cartilage tissue the products of GDAS utilization e.g. a number of peroxides, in particular hydrogen peroxide, derivatives of peroxidation of proteins, fatty and nucleic acids.

Therefore, the development of MIA-induced OA caused an intensification of oxidative stress, which proved by the increase of superoxide radical, hydrogen peroxide, products of LPO (diene conjugates, TBA-active products, Schiff bases), increase catalase and superoxide dismutase activity, depletion of GDAS. Administration of PB to animals with MIA-OA caused restoration of oxidative-antioxidant balance and can indicate antioxidant properties of the studied PB composition.

So, activation of free radical processes is associated in OA with the development of inflammation and cartilage damage, resulting in the decomposition products $[44,45]$. The degradation processes during OA are directed not only at the cartilage cells but also at the substances of the cartilage extracellular matrix, mainly collagen II and proteoglycans. The proteolysis system of ECM includes MMPs, that directly involved in the destruction of joint tissues. Producing of MMPs activates in synoviocytes, chondrocytes, fibroblasts, and osteoblasts [46]. The regulatory mechanisms of MMPs synthesis and secretion are pretty complex, it includes the implication of cytokines, growth factors, integrins, and chemical compounds such as phorbol esters, lipopolysaccharides, prostaglandin E $[47,48]$. In our previous studies, we have shown an increase in the concentration of pro-inflammatory cytokines in serum and the increase in the Ptgs2, Tgfb1, Nos2 genes expression and the decrease in the Acan, Col2 genes expression in cartilage in MIA-OA [49-52].

The conditions of experimental OA caused an increase of MMPs in the cartilage homogenates of rats (Figure). MMP1 increased in 4.3 times, MMP2 in 2.7 times, MMP3 in 3.8 times and MMP8 in 3.1 times, compared to control group. This data indicate the development of destructive processes in the knee joint of animals.

The administration on PB to animals with MIA-OA reduced the levels of MMPs in the cartilage homogenates: MMP-1, MMP-2 and MMP-3 in 1.3 times and MMP-8 in 1.4 times, compared to MIA-OA group. The administration of studied PB composition to animals without MIA-OA did not change the parameters of MMPs, compared to control group.

Our data confirmed the development of oxidative stress and degradation of cartilage under conditions of MIA-OA. The decrease of the intensity of free radical processes and the level of MMPs in the cartilage of the joint during long-term administration of studied PB indicates the anti-inflammatory and antioxidant properties of the composition. Also, our findings showed a wide range of biological activity of the studied PB composition. It includes the ability to effectively restore the disturbed microbiome balance and reduce the development of inflammatory and degenerative processes in cartilage [53-54]. Also, the ability of bacterial strains of the composition to synthesize biologically active metabolites (vitamins, short-chain fatty acids, antioxidants, and immunomodulators) is important in restoring of the homeostasis [55-57].

Conclusion. The conditions of experimental OA disrurb oxidative-antioxidative balance in knee cartilage and changes in levels of MMPs that lead to 

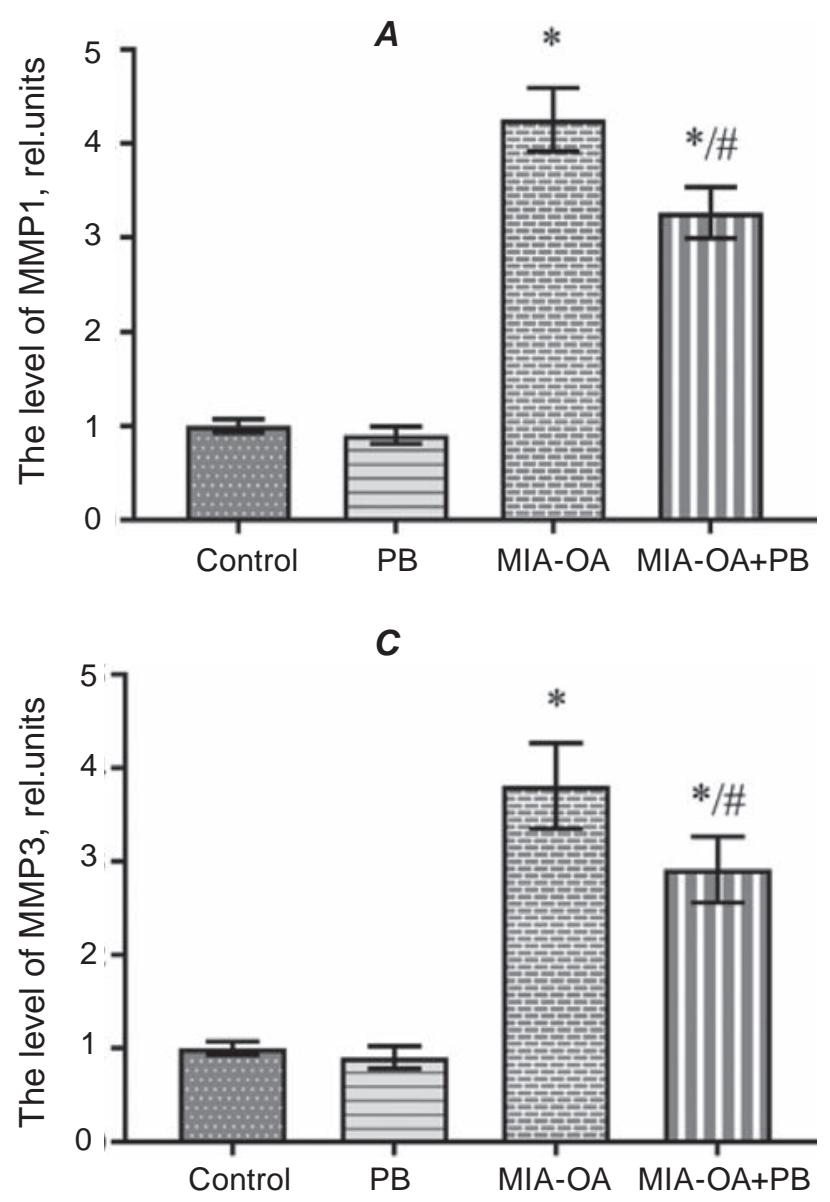

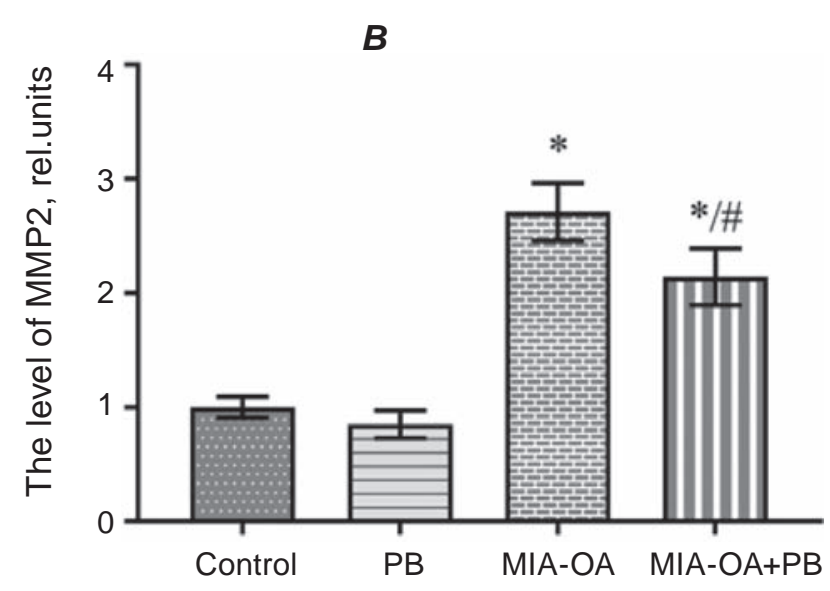

D

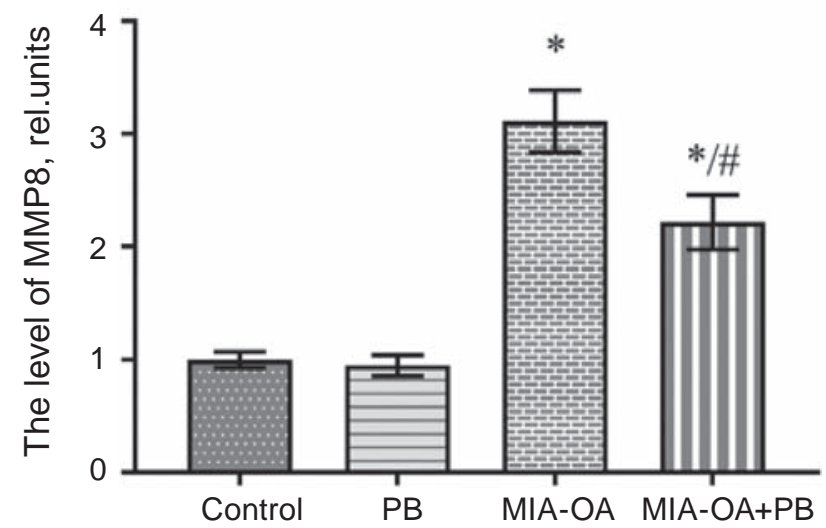

The levels of matrix metalloproteinases (MMPs)-1 (A), -2 (B), -3 (C), -8 (D) in cartilage tissue of knee joints of rats with monoiodoacetate-induced osteoarthritis (MIA-OA) and administration of probiotic (PB) composition $\left(n=14\right.$ in each group). $* P<0.05$ compared with Control group; ${ }^{*} P<0.05$ compared with MIA-OA group

enhance of cartilage degeneration. Administration of the $\mathrm{PB}$ composition have a promising effect on the oxidative-antioxidant status and the levels of MMPs in cartilage tissue of rats with experimental OA and may be concerned as an important anti-inflammatory and antioxidant agent for further clinical trials.

Conflict of interest. Authors have completed the Unified Conflicts of Interest form at http://ukrbiochemjournal.org/wp-content/uploads/2018/12/ coi_disclosure.pdf and declare no conflict of interest.
Funding. The study was supported in part by budget topic of Ministry of Education of Ukraine 18БП036-02 "Development of methodical recommendations for administration of chondroprotectors and multiprobiotics for joint pathology treatment. Applied scientific research" (2018-2020 academic years). 
ОКСИДАНТНО/

АНТИОКСИДАНТНИЙ БАЛАНС

ТА РІВЕНЬ МАТРИЧНИХ

МЕТАЛОПРОТЕЇНАЗ У ЩУРІВ

З ЕКСПЕРИМЕНТАЛЬНИМ

ОСТЕОАРТРИТОМ ЗА ВВЕДЕННЯ ПРОБІОТИКА

О. Короткий

Т. Вовк, М. Тимошенко, Л. Остапченко

\author{
ННЦ «Інститут біології та медицини», \\ Київський національний університет \\ імені Тараса Шевченка, Україна; \\ 凶e-mail: korotkyi@gmail.com
}

У роботі досліджували вплив багатокомпонентного пробіотика на оксидантно/ антиоксидантний баланс та рівень матричних металопротеїназ (ММР) у хрящовій тканині колінного суглоба щурів за експериментального остеоартриту. Остеоартрит (ОА) було індуковано одноразовою ін'єкцією монойодоацетату в колінний суглоб щурів. Введення пробіотика проводили щодня протягом 14 днів. У гомогенізованих хрящах коліна щурів оцінювали вміст активних форм кисню (супероксид-аніон та пероксид водню), продуктів пероксидного окислення ліпідів (дієнових кон'югатів, ТБКактивних продуктів, шиффових основ) та визначали активність супероксиддисмутази, каталази, глутатіонзалежних антиоксидантних ензимів i рівень відновленого/окисленого глутатіону. Рівень експресії МMP-1, -2, -3, -8 визначали методом ELISA. Показано, що за остеоартриту в щурів значно підвищувалися вміст активних форм кисню та продуктів пероксидного окислення ліпідів, активність супероксиддисмутази та каталази, а також рівень всіх досліджуваних MMP, у той самий час спостерігали виснаження глутатіонзалежної антиоксидантної системи та зменшення співвідношення між відновленим та окисленим глутатіоном. За введення пробіотика в щурів з ОА спостерігали тенденцію відновлення параметрів до значень контрольної групи. Таким чином, введення пробіотика щурам із остеоартритом може розглядатися як протизапальний та антиоксидантний засіб у подальших клінічних випробуваннях.

К л юч о в $\quad$ слов а: остеоартрит, пробіотик, вільнорадикальні процеси, глутатіон, матричні металопротеїнази.

\section{References}

1. Hunter DJ, Bierma-Zeinstra S. Osteoarthritis. Lancet. 2019; 393(10182): 1745-1759.

2. O'Neill TW, McCabe PS, McBeth J. Update on the epidemiology, risk factors and disease outcomes of osteoarthritis. Best Pract Res Clin Rheumatol. 2018; 32(2): 312-326.

3. Korotkyi O, Kyriachenko Y, Kobyliak N, Falalyeyeva T, Ostapchenko L. Crosstalk between gut microbiota and osteoarthritis: A critical view. J Funct Foods. 2020; 68: 103904.

4. Man GS, Mologhianu G. Osteoarthritis pathogenesis - a complex process that involves the entire joint. J Med Life. 2014; 7(1): 37-41.

5. Vitetta L, Coulson S, Linnane AW, Butt H. The gastrointestinal microbiome and musculoskeletal diseases: a beneficial role for probiotics and prebiotics. Pathogens. 2013; 2(4): 606-626.

6. Bravo-Blas A, Wessel H, Milling S. Microbiota and arthritis: correlations or cause? Curr Opin Rheumatol. 2016; 28(2): 161-167.

7. Fomenko I, Bondarchuk T, Emelyanenko V, Denysenko N, Sklyarov P, Ilkiv I, Lesyk R, Sklyarov A. Changes of nitric oxide system and lipid peroxidation parameters in the digestive system of rats under conditions of acute stress, and use of nonsteroidal anti-inflammatory drugs. Curr Issues Pharm Med Sci. 2015; 28(1): 37-41.

8. Korotkyi OH, Luhovska TV, Serhiychuk TM, Dvorshchenko KO, Falalyeyeva TM, Ostapchenko LI. The gut microbiota of rats under experimental osteoarthritis and administration of chondroitin sulfate and probiotic. Mikrobiol Zhurn. 2020; 82(6): 64-73.

9. Dvorshchenko KO, Bernyk OO, Dranitsina AS, Senin SA, Ostapchenko LI. Influence of oxidative stress on the level of genes expression TGFB1 and HGF in rat liver upon long-term gastric hypochlorhydria and administration of multiprobiotic Symbiter. Ukr Bikhim Zhurn. 2013; 85(5): 114-123. (In Ukrainian).

10. Dvorshchenko KO, Vakal SI, Dranitsina AS, Senin SA, Ostapchenko LI. Stress-responsive systems in rat pancreas upon long-term gastric hypochlorhydria and administration of multiprobiotic "Symbiter”. Ukr Biokhim Zhurn. 2013; 85(2): 68-77. (In Ukrainian).

11. Korotkyi O, Dvorshchenko K, Falalyeyeva T, Sulaieva O, Kobyliak N, Abenavoli L, Fagoonee S, Pellicano R, Ostapchenko L. Combined effects of probiotic and chondroprotector during 
osteoarthritis in rats. Panminerva Med. 2020; 62(2): 93-101.

12. Drevet S, Gavazzi G, Grange L, Dupuy C, Lardy B. Reactive oxygen species and NADPH oxidase 4 involvement in osteoarthritis. Exp Gerontol. 2018; 111: 107-117.

13. Baragi VM, Becher G, Bendele AM, Biesinger R, Bluhm H, Boer J, Deng H, Dodd R, Essers M, Feuerstein T, Gallagher BM Jr, Gege C, Hochgürtel M, Hofmann M, Jaworski A, Jin L, Kiely A, Korniski B, Kroth H, Nix D, Nolte B, Piecha D, Powers TS, Richter F, Schneider M, Steeneck C, Sucholeiki I, Taveras A, Timmermann A, Van Veldhuizen J, Weik J, Wu X, Xia B. A new class of potent matrix metalloproteinase 13 inhibitors for potential treatment of osteoarthritis: Evidence of histologic and clinical efficacy without musculoskeletal toxicity in rat models. Arthritis Rheum. 2009; 60(7): 2008-2018.

14. Mehana EE, Khafaga AF, El-Blehi SS. The role of matrix metalloproteinases in osteoarthritis pathogenesis: An updated review. Life Sci. 2019; 234: 116786.

15. Korotkyi O, Vovk A, Galenova T, Vovk T, Dvorshchenko K, Luzza F, Abenavoli L, Kobyliak N, Falalyeyeva T, Ostapchenko L. Effect of probiotic on serum cytokines and matrix metalloproteinases profile during monoiodoacetate-induced osteoarthritis in rats. Minerva Biotecnol. 2019; 31(2): 68-73.

16. Korotkyi O, Dvorshchenko K, Vovk A, Dranitsina A, Tymoshenko M, Kot L, Ostapchenko L. Effect of probiotic composition on oxidative/antioxidant balance in blood of rats under experimental osteoarthritis. $U \mathrm{kr}$ Biochem J. 2019; 91(6): 49-58.

17. Guzman RE, Evans MG, Bove S, Morenko B, Kilgore K. Mono-iodoacetate-induced histologic changes in subchondral bone and articular cartilage of rat femorotibial joints: an animal model of osteoarthritis. Toxicol Pathol. 2003; 31(6): 619-624.

18. Multiprobiotic Symbiter acidophilus. Regime of access : https://symbiter.ua/uk/multiprobioticssymbiter-ua/symbiter-acidophilic-ua.html (last accessed 17.07.2020).

19. Able AJ, Guest DI, Sutherland MW. Use of a new tetrazolium-based assay to study the production of superoxide radicals by tobacco cell cultures challenged with avirulent zoospores of
Phytophthora parasitica var nicotianae. Plant Physiol. 1998; 117(2): 491-499.

20. Jiang ZY, Woollard AC, Wolff SP. Hydrogen peroxide production during experimental protein glycation. FEBS Lett. 1990; 268(1): 69-71.

21. Nourooz-Zadeh J, Tajaddini-Sarmadi J, Wolff SP. Measurement of plasma hydroperoxide concentrations by the ferrous oxidationxylenol orange assay in conjunction with triphenylphosphine. Anal Biochem. 1994; 220(2): 403-409.

22. Gavrilov VB, Gavrilova AR, Khmara NF. Measurement of diene conjugates in blood plasma using the UV absorption of heptane and isopropanol extracts. Lab Delo. 1988; (2): 60-64. (In Russian).

23. Kolesova OE, Markin AA, Fedorova TN. Lipid peroxidation and methods of determining its products in biological media. Lab Delo. 1984; (9): 540-546. (In Russian).

24. Stalnaia ID, Garishvili TG. A method for determination of malondialdehyde with tiobarbituric acid. Modern methods in biochemistry. M.: Meditsina, 1977. P. 66-68 (In Russian).

25. Chevari S, Chaba I, Sekei I. Role of superoxide dismutase in cellular oxidative processes and method of its determination in biological materials. Lab Delo. 1985; (11): 678-681. (In Russian).

26. Koroliuk MA, Ivanova LK, Maiorova IG, Tokarieva VA. A method for determination of catalase. Lab Delo. 1988; (4): 44-47. (In Russian).

27. Vlasova SN, Shabunina EI, Pereslegina IA.The activity of the glutathione-dependent enzymes of erythrocytes in chronic liver diseases in children. Lab Delo. 1990; (8): 19-22. (In Russian).

28. Hissin PJ, Hilf R. A fluorometric method for determination of oxidized and reduced glutathione in tissues. Anal Biochem. 1976; 74(1): 214-226.

29. Mokrasch LC, Teschke EJ. Glutathione content of cultured cells and rodent brain regions: a specific fluorometric assay. Anal Biochem. 1984; 140(2): 506-509.

30. Lowry OH, Rosebrough NJ, Farr AL, Randall RJ. Protein measurement with the Folin phenol reagent. J Biol Chem. 1951; 193(1): 265-275.

31. Malfait AM. Osteoarthritis year in review 2015: biology. Osteoarthritis Cartilage. 2016; 24(1): 21-26. 
32. Lepetsos P, Papavassiliou AG. ROS/oxidative stress signaling in osteoarthritis. Biochim Biophys Acta. 2016; 1862(4): 576-591.

33. Afonso V, Champy R, Mitrovic D, Collin P, Lomri A. Reactive oxygen species and superoxide dismutases: role in joint diseases. Joint Bone Spine. 2007; 74(4): 324-329.

34. Na JY, Song K, Kim S, Kwon J. Rutin protects rat articular chondrocytes against oxidative stress induced by hydrogen peroxide through SIRT1 activation. Biochem Biophys Res Commun. 2016; 473(4): 1301-1308.

35. Xue L, Li X, Chen Q, He J, Dong Y, Wang J, Shen S, Jia R, Zang QJ, Zhang T, Li M, Geng Y. Associations between D3R expression in synovial mast cells and disease activity and oxidant status in patients with rheumatoid arthritis. Clin Rheumatol. 2018; 37(10): 26212632.

36. Yin G, Li Y, Yang M, Cen XM, Xie QB. Pim2/mTORC1 Pathway Shapes Inflammatory Capacity in Rheumatoid Arthritis Synovial Cells Exposed to Lipid Peroxidations. Biomed Res Int. 2015; 2015: 240210.

37. Shan L, Tong L, Hang L, Fan H. Fangchinoline supplementation attenuates inflammatory markers in experimental rheumatoid arthritisinduced rats. Biomed Pharmacother. 2019; 111: 142-150.

38. Rieder B, Weihs AM, Weidinger A, Szwarc D, Nürnberger $S$, Redl $H$, Rünzler $D$, HuberGries C, Teuschl AH. Hydrostatic pressuregenerated reactive oxygen species induce osteoarthritic conditions in cartilage pellet cultures. Sci Rep. 2018; 8(1): 17010.

39. van Dalen SCM, Kruisbergen NNL, Walgreen B, Helsen MMA, Slöetjes AW, Cremers NAJ, Koenders MI, van de Loo FAJ, Roth J, Vogl T, Blom AB, van der Kraan PM, van Lent PLEM, van den Bosch MHJ. The role of NOX2-derived reactive oxygen species in collagenase-induced osteoarthritis. Osteoarthritis Cartilage. 2018; 26(12): 1722-1732.

40. Abusarah J, Bentz M, Benabdoune H, Rondon PE, Shi Q, Fernandes JC, Fahmi H, Benderdour M. An overview of the role of lipid peroxidationderived 4-hydroxynonenal in osteoarthritis. Inflamm Res. 2017; 66(8): 637-651.

41. Vnukov VV, Krolevets IV, Milutina NP, Gutsenko OI, Zabrodin MA, Panina SB, Gvaldin DYu, Plotbikov AA, Shevyakova EA,
Braznikov YuI. Free radical oxidation in synovial fluid and apoptosis of chondrocytes in osteoarthritis of knee. Valeology. 2012; (4): 3844. (In Russian).

42. Wu Q, Zhong ZM, Zhu SY, Liao CR, Pan Y, Zeng JH, Zheng S, Ding RT, Lin QS, Ye Q, Ye WB, Li W, Chen JT. Advanced oxidation protein products induce chondrocyte apoptosis via receptor for advanced glycation end productsmediated, redox-dependent intrinsic apoptosis pathway. Apoptosis. 2016; 21(1): 36-50.

43. He L, He T, Farrar S, Ji L, Liu T, Ma X. Antioxidants maintain cellular redox homeostasis by elimination of reactive oxygen species. Cell Physiol Biochem. 2017; 44(2): 532553.

44. Zahan OM, Serban O, Gherman C, Fodo D. The evaluation of oxidative stress in osteoarthritis. Med Pharm Rep. 2020; 93(1): 12-22.

45. Iolascon G, Gimigliano F, Moretti A, de Sire A, Migliore A, Brandi ML, Piscitelli P. Early osteoarthritis: How to define, diagnose, and manage. A systematic review. Eur Geriatr Med. 2017; 8(5-6): 383-396.

46. Cui N, Hu M, Khalil RA. Biochemical and biologicalattributes of matrixmetalloproteinases. Prog Mol Biol Transl Sci. 2017; 147: 1-73.

47. Li H, Xie S, Qi Y, Li H, Zhang R, Lian Y. TNF- $\alpha$ increases the expression of inflammatory factors in synovial fibroblasts by inhibiting the PI3K/ AKT pathway in a rat model of monosodium iodoacetate-induced osteoarthritis. Exp Ther Med. 2018; 16(6): 4737-4744.

48. Malemud CJ. Matrix metalloproteinases and synovial joint pathology. Prog Mol Biol Transl Sci. 2017; 148: 305-325.

49. Korotkyi O, Vovk A, Blokhina O, Dvorshchenko K, Falalyeyeva T, Abenavoli L, Ostapchenko L. Effect of chondroitin sulfate on blood serum cytokine profile during carrageenan-induced edema and monoiodoacetateinduced osteoarthritis in Rats. Rev Recent Clin Trials. 2019; 14(1): 50-55.

50. Dranitsina AS, Dvorshchenko KO, Korotkyi AG, Grebinyk DM, Ostapchenko LI. Expression of Ptgs2 and Tgfb1 genes in rat cartilage cells of the Knee under conditions of osteoarthritis. Cytol Genet. 2018; 52(3): 192-197.

51. Dranitsina AS, Dvorshchenko KO, Korotkyi OH, Vovk AA, Falalyeyeva TM, Grebinyk DM, Ostapchenko LI. Expression of Nos2 and 
Acan genes in rat Knee articular cartilage in osteoarthritis. Cytol Genet. 2019; 53(6): 481-488.

52. Korotkyi OH, Vovk AA, Dranitsina AS, Falalyeyeva TM, Dvorshchenko KO, Fagoonee S, Ostapchenko LI. The influence of probiotic diet and chondroitin sulfate administration on Ptgs2, Tgfb1 and Col2a1 expression in rat knee cartilage during monoiodoacetate-induced osteoarthritis. Minerva Med. 2019; 110(5): 419-424.

53. Korotkyi O, Vovk A, Kuryk O, Dvorschenko K, FalalyeyevaT, OstapchenkoL.Co-administration of live probiotics with chondroprotector in management of experimental knee osteoarthritis. Georgian Med News. 2018; (279): 191-196.

54. Korotkyi OH, Vovk AA, Halenova TI, Vovk TB, Dvorshchenko KO, Falalyeyeva TM, Ostapchenko LI. Cytokines profile in knee cartilage of rats during monoiodoacetateinduced osteoarthritis and administration of probiotic. Biopolym Cell. 2020; 36(1): 22-34.
55. Kompanets I, Korotkiy A, Karpovets T, Ostapchenko L, Pilipenko S, Yankovskiy D. The interferon production and 2',5'-oligoadenylatesynthetase activity in rat spleen lymphocytes at hypoacidity evoked by omeprazole injection and at administration of multiprobiotic «SYMBITER $® »$. Curr Issues Pharma Med Sci. 2013; 26(4): 398-400.

56. Xu C, Shi Z, Shao J, Yu C, Xu Z. Metabolic engineering of Lactococcus lactis for high level accumulation of glutathione and S-adenosylL-methionine. World J Microbiol Biotechnol. 2019; 35(12): 185.

57. Wieërs G, Belkhir L, Enaud R, Leclercq S, Philippart de Foy JM, Dequenne I6, de Timary P, Cani PD. How probiotics affect the microbiota. Front Cell Infect Microbiol. 2020; 9: 454. 